\title{
Probiotic Properties of Bacillus subtilis Isolated from Dried Anchovies (Stolephorus indicus) and Evaluating its Antimicrobial, Antibiofilm and Growth-Enhancing Potential in Danio rerio
}

\author{
Thejaswi Bhandary, Riyaz Ali.L, Kuppusamy Alagesan Paari*
}

Department of Life Sciences, CHRIST (Deemed to be University), Hosur main road, Bangalore, Karnataka, India 560029.

\begin{abstract}
The study was aimed at isolating and characterising a potential probiotic bacterium from dried anchovies (Stolephorus indicus) and evaluating its antibacterial, antibiofilm and growth enhancing potential in Danio rerio. The isolate was identified as Bacillus subtilis using $16 \mathrm{~S}$ rRNA sequencing and phylogenetic analysis. Probiotic properties were characterised based on the ability of the isolated strain to survive in simulated gastric juice and trypsin. Isolated strain was further subjected to varying $\mathrm{pH}$, temperature, different concentrations of organic solvents to evaluate its potential to tolerate stress. Biofilm inhibition against Vibrio harveyi (31.5 $\pm 4.6 \%)$, Escherichia coli $(28.8 \pm 4.2 \%)$, Pseudomonas aeruginosa $(34.8 \pm 3.1 \%)$ and Staphylococcus aureus $(34.4 \pm 3.75 \%)$ was noted. The study showed that the isolate improved the survival rate of Danio rerio against Vibrio harveyi and Escherichia coli. The weight $(12.77 \pm 0.06)$ and length $(11.413 \pm 0.18)$ gain percentage was numerically ( $p>0.05)$ improved in probiotic supplemented groups as compared to control. The use of probiotics from non-conventional sources can improve the diversity of the available probiotics for aquaculture practices
\end{abstract}

Keywords | Bacillus subtilis, Probiotic, Aquaculture, Anti-bacterial, Anti-biofilm, Growth enhancement

Received | March 14, 2021; Accepted | April 15, 2021; Published | June 15, 2021

*Correspondence | Kuppusamy Alagesan Pari, Department of Life Sciences, CHRIST (Deemed to be University), Hosur main road, Bangalore, Karnataka, India 560029; Email: paari.ka@christuniversity.in

Citation | Bhandary T, Ali L Riyaz, Paari KA (2021). Probiotic properties of bacillus subtilis isolated from dried anchovies (stolephorus indicus) and evaluating its antimicrobial, antibiofilm and growth-enhancing potential in danio rerio. J. Anim. Health Prod. 9(3): $205-212$.

DOI | http://dx.doi.org/10.17582/journal.jahp/2021/9.3.205.212

ISSN | 2308-2801

Copyright (C) 2021 Ali L et al. This is an open access article distributed under the Creative Commons Attribution License, which permits unrestricted use, distribution, and reproduction in any medium, provided the original work is properly cited.

\section{INTRODUCTION}

A mong the various food production sectors, aquaculture is the most rapidly growing. The average annual increase in global consumption of fish (3.2\%) outpaced the average growth in population (1.6\%) between 1961 and 2016 (FAO, 2018). Coupled with this growth are the various concerns related to the safety and quality of the fish due to overproduction to meet the needs of billions of people around the globe. One of the major constraints in the field of aquaculture is the surge in disease outbreaks. Antibiotics have been the go-to option to combat disease outbreaks (Satish et al., 2011). Over-prescription of antibiotics in clinical setups and in the food industry to the emergence of antibiotic resistant microorganisms such as Staphylococcus aureus, Enterococci, and Streptococcus pneumoniae (Hols et al., 2019). Due to the growing concerns about the use and abuse of antibiotics, alternatives such as probiotics are emerging as a safer and beneficial alternative (Satish et al., 2011).

A probiotic is a cultured product or live microbial feed supplement, which beneficially affects the host by improving the intestinal microflora (Fuller, 1989). Probiotics are mostly associated with the gastrointestinal tract, where they are antagonistic to pathogenic bacteria (Hoseinifar et al., 2018). Some of the mechanisms by which the probiotics confer beneficial effects to the host are by causing 
the exclusion of pathogenic microorganisms (Gayathri and Rashmi, 2016), improving the host immune response by producing antibacterial substances such as antibiotics, bacteriocins (Gaspar et al., 2018; Hoseinifar et al., 2018), siderophores (Panda et al., 2017), alteration of $\mathrm{pH}$ by organic acid production and by the production of hydrogen peroxide under aerobic growth conditions (Pavlova, 2020). Probiotics are also known to reduce mutagenesis by directly binding to mutagenic compounds thereby reducing their absorption in the intestine (Orrhage et al., 1994), and reduce cholesterol production through the production of short-chain fatty acids (Pereira and Gibson, 2002).

Researchers have relied on different sources for the isolation of potential probiotic bacteria. The conventional sources are dairy products and the gastrointestinal tract of healthy humans. However, research conducted over the years has highlighted the use of alternate sources such as the gastrointestinal tract of other animals, traditional fermented vegetables, fruits, and dried fish (Zielińska and Kolożyn, 2018; Singh et al., 2012). One example of such an unconventional source, dry fish, has been gaining popularity. There has been an increase in the production of dry fish with about $17 \%$ of the total catch in Indian fisheries being used for the production of dry fishes (Bharda et al., 2017). Mackerel, tuna, oil sardines, lesser sardines, silver bellies, mullets, ribbon fishes, and anchovies are some of the species commonly subjected to dry fish production in India (Siriskar et al., 2013, Logesh et al., 2012). Dried anchovies (Stolephorus indicus) form an important component of purse-seine fishery of the Indian coast that are found mostly along the coastal areas of India and are widely consumed as salted or in dried form (Siriskar et al., 2013). Traditionally dried anchovies are a potentially unique source of probiotic bacteria (Alkalbani, 2019). Thus, the current study was conducted with the following objectives: (1) to isolate potential probiotic bacteria from dried anchovy fish and characterize their probiotic properties and (2) to decipher its use in combating pathogens, enhancing the growth and survival rates in fishes.

\section{MATERIALS AND METHODS}

\section{IsOlation, IDENTIFICATION AND CHARACTERISATION}

The isolation source for probiotics was dried Anchovy fish (Stolephorus indicus). MRS (De Man-Rogosa-Sharpe) media was used for isolating the culture. The isolate was identified using 16SrRNA sequencing using forward (16SrRNA-F) and reverse (16SrRNA-R) primers by BDT v3.1 cycle sequencing kit on ABI 3730xl Genetic Analyzer. Gram's staining, IMViC test, motility and catalase tests were performed as preliminary evaluation (Hoque et al., 2010). The isolate was screened for its antimicrobial (Kavitha et al., 2018) and haemolytic activity (Halder et al.,
2017) before further characterisation.

\section{PH, TEMPERATURE AND TOLERANCE TEST}

Characterisation was done according to the protocol of $\mathrm{Ya}^{-}$ dav et al. (2016) with slight modifications. The isolate was exposed to varying $\mathrm{pH}(2-10)$, temperature $\left(15^{\circ} \mathrm{C}-55^{\circ} \mathrm{C}\right)$, sodium chloride concentrations (2\%-10\%) and solvent concentrations $(0.2 \%-0.6 \%)$. After incubation for $24 \mathrm{~h}$, the culture was plated onto MRS agar plates and the Log $\left(\mathrm{CFU} \cdot \mathrm{mL}^{-1}\right.$ ) was calculated (Zheng et al., 2013).

Artificial gastric juice tolerance and trypsin tolerance test: The test was performed according to the protocol described by Corcoran et al. (2005) with slight modifications. The composition of the artificial gastric juice was Glucose $(0.35$ $\mathrm{g}), \mathrm{NaCl}(0.20 \mathrm{~g}), \mathrm{KH}_{2} \mathrm{PO}_{4}(0.06 \mathrm{~g}), \mathrm{CaCl}_{2}(0.01 \mathrm{~g}), \mathrm{KCl}$ $(0.03 \mathrm{~g})$ and Pepsin $(0.03 \mathrm{~g})$ per $100 \mathrm{~mL}$. All components of gastric juice were added as stock in the media prior to inoculation of culture. An overnight culture of the isolate was inoculated into artificial gastric juice and incubated at $37^{\circ} \mathrm{C}$ for time duration of 2,4 and $6 \mathrm{~h}$. Similarly, the isolate was subjected to varying concentrations $(0.2 \%-0.6 \%)$ of trypsin. The isolate was treated with trypsin for a period of $6 \mathrm{~h}$. The cell viability was expressed in $\log \left(\mathrm{CFU} \cdot \mathrm{mL}^{-1}\right)$ after plating onto MRS agar for $24 \mathrm{~h}$ at $37^{\circ} \mathrm{C}$.

\section{IN VIVO CHALLENGE AND GROWTH STUDIES}

Challenge studies were performed according to the protocol of Wang et al. (2008) with slight modifications. A total of 180 healthy Zebrafish (Danio rerio) weighing (0.1-0.15 g) were segregated into triplicates in the following groups; Group treated with saline, group treated with probiotic only, group treated with pathogens (Vibrio harveyi and Escherichia coli) and a final group constituting pathogens along with the isolate. The survival rate in $D$. rerio was determined by supplementing $6 \mathrm{Log}\left(\mathrm{CFU} \cdot \mathrm{mL}^{-1}\right)$ of the isolate against Escherichia coli and Vibrio harveyi $(6 \mathrm{Log}$ $\left(\mathrm{CFU} \cdot \mathrm{mL}^{-1}\right)$. Parameters such as feed conversion ratio, weight gain percentage and length gain percentage were monitored for a period of 15 days.

\section{AnTibiofilm Activity}

Escherichia coli, Pseudomonas aeruginosa, Vibrio harveyi and Staphylococcus aureus were allowed to form biofilm in a microtiter plate. The antibiofilm activity was measured using a microplate reader (iMark ${ }^{\mathrm{TM}}$ Microplate Absorbance Read$\mathrm{er}$, Biorad) set at $450 \mathrm{~nm}$ and the percentage inhibition was calculated (Costa et al., 2018).

\section{Statistical Analysis}

The results are presented as Mean \pm SD of triplicates. The various parameters analyzed were subjected to statistical analysis using one way ANOVA and independent t-test with $\mathrm{p}<0.05$ being considered significant. 
Table 1: General characteristics of the isolated Bacillus subtilis

\begin{tabular}{lll} 
Colony morphology & $\begin{array}{l}\text { White,round,opaque, medium and } \\
\text { smooth } \\
\text { Gram positive, bacilli }\end{array}$ & $\begin{array}{l}\text { (Lu et al., 2018) } \\
\text { (Seenivasan et al., 2012) }\end{array}$ \\
Gram's staining and Shape & + & (Lu et al., 2018) \\
Catalase test & Motile & (Liu et al., 2009) \\
Motility test & $+-+^{* *}$ & (Seenivasan et al., 2012) \\
\hline IMViC test* & Gamma Hemolytic & (Zulkhairi et al., 2019) \\
\hline Haemolysis assay & - & (Wu et al. 2013) \\
\hline Milk coagulation efficacy & ++ & (Nithya and Halami, 2012) \\
Growth at 0.6\% trypsin & ++ & (Kavitha et al. 2018) \\
\hline Antimicrobial well diffusion test & - & (Hoque et al. 2010)
\end{tabular}

*Indole, Methyl red, Voges-Proskauer and Simmon citrate test.

${ }^{* *}$ Consecutive values according to IMViC test

\section{RESULTS AND DISCUSSION}

The isolate was identified as Bacillus subtilis using $16 \mathrm{~S}$ rRNA sequencing and the partial sequence was deposited in NCBI (Accession number-MN960600). The evolutionary history was inferred using the Maximum Likelihood method and Tamura-Nei model and a phylogenetic tree was constructed (Tamura and Nei, 1993) (Figure 1) and the closest relative was identified as Bacillus subtilis. The genus Bacillus comprises a diverse group of organisms that offer a wide range of nutritional, physiological and metabolic diversity (Sen et al., 2015). B. subtilis has been widely used due to its antimicrobial activity to tackle fish pathogens in commercial aquaculture (Wu et al., 2018; Kong et al., 2017). The isolate in the study was biochemically characterised (Table 1 ) and screened for its anti-microbial activity against pathogens like $E$. coli and $V$. harveyi.

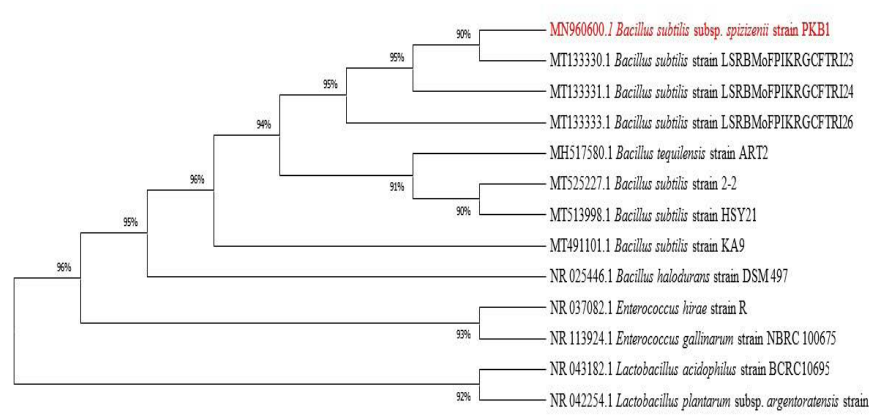

Figure 1: depicts MEGA-X phylogenetic analysis of Bacillus sp. isolate. The tree with the highest log likelihood $(-4108.98)$ is shown. Initial tree(s) for the heuristic search were obtained by applying Neighbour-Join and BioNJ algorithms to a matrix of pairwise distances estimated using the Maximum Composite Likelihood (MCL) method and then selecting the topology with superior log likelihood value. The tree was drawn to scale, with branch lengths measured in the number of substitutions per site.
The isolate in this study was able to tolerate temperature up to $45^{\circ} \mathrm{C}$ and the growth subsided beyond $45^{\circ} \mathrm{C}$ (Figure 2). Minimal or no growth was reported at lower temperature ranges below $25^{\circ} \mathrm{C}$ (data not shown). Probiotics can rarely tolerate temperature changes beyond $50^{\circ} \mathrm{C}$ (Ding and Shah, 2007). Thermal resistance in probiotics is key in determining survival ability since fluctuations in temperature in external or internal environments can lead to cell death (Champagne et al., 1993).

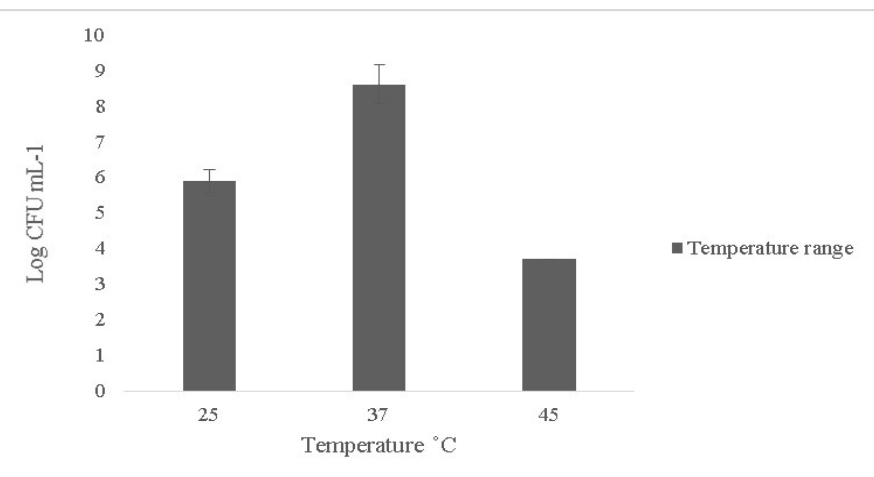

Figure 2: Thermal tolerance of Bacillus subtilis-MN960600 on upshifts and downshifts from $37^{\circ} \mathrm{C}$ *Error bars indicate the standard deviation, the values are expressed as Mean \pm SD of triplicates

The isolate showed maximum growth at $\mathrm{pH}$ 6-7 with 8.1 $\pm 0.4 \mathrm{Log} \mathrm{CFU} \cdot \mathrm{mL}^{-1}$ and growth was $7.6 \pm 0.1 \mathrm{Log}$ $\mathrm{CFU} \cdot \mathrm{mL}^{-1}$ at $\mathrm{pH} 4$. No growth was observed at $\mathrm{pH} 2$ and the growth dropped by over $1.1 \pm 0.2 \mathrm{Log} \mathrm{CFU} \cdot \mathrm{mL}^{-1}$ at $\mathrm{pH}$ ranges of 8-10 (Figure 3). B. subtilis is able to tolerate varied ranges of $\mathrm{pH}$ and the optimum $\mathrm{pH}$ showing maximum activity ranges between 5 to 7 (Cotter and Hill, 2003). Bacillus sp. are known to tolerate acidic conditions ( $\mathrm{pH}$ 2.5) and such candidates are suitable to be employed as starter cultures as they are able to survive the internal gastric environment and possess lesser or equal enzymatic activities (Krulwich et al., 1985; Jeon et al., 2017). The ability of the isolate to tolerate wide ranges of $\mathrm{pH}$ fluctuations exerts its 
antimicrobial activity in the extreme pathogenic environment.

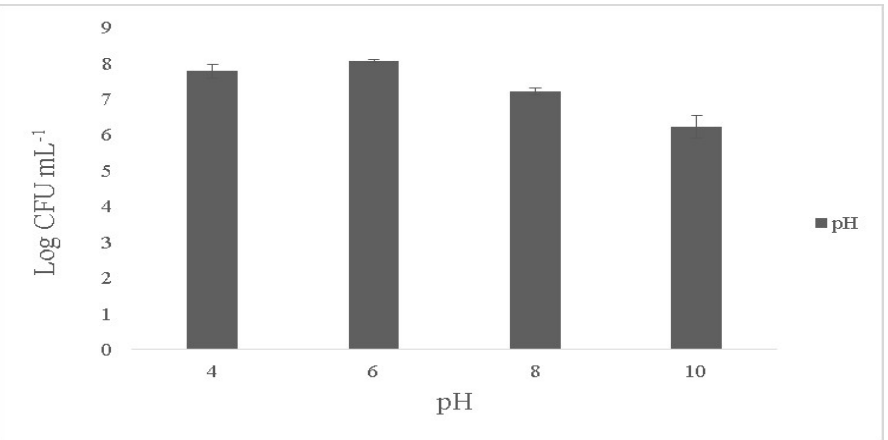

Figure 3: Effect of $\mathrm{pH}$ on the survival of the Bacillus subtilis-MN960600. ${ }^{*}$ The data are means of triplicate experiments and error bars indicate standard deviations.

Another probiotic characteristic is the ability to survive in the internal gastric environment (Ding and Shah, 2007). The isolate was checked for its ability to survive in simulated artificial gastric juice for time duration of 2, 4 and $6 \mathrm{~h}$ mimicking the estimated time to be spent in the gastrointestinal tract (Figure 4). The final growth observed after $6 \mathrm{~h}$ was $7.0 \pm 0.31 \mathrm{Log}\left(\mathrm{CFU} \cdot \mathrm{mL}^{-1}\right)$.

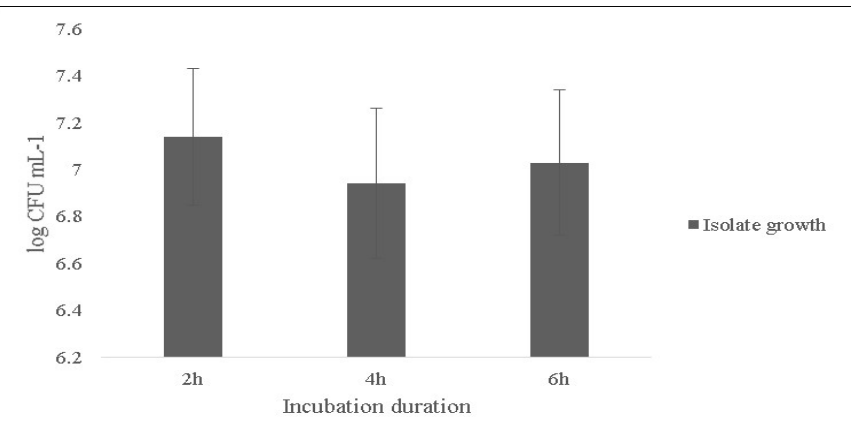

Figure 4: Survival of the Bacillus subtilis-MN960600 in artificial gastric juice at durations $2 \mathrm{~h}, 4 \mathrm{~h}$ and $6 \mathrm{~h}$. ${ }^{*}$ Error bars indicate the standard deviation; the values are expressed as Mean \pm SD of triplicates

Salt tolerance can influence the water and enzymatic activity of bacterial strains and confers high osmotolerance to withstand excessive external osmotic pressure (Adnan and Tan, 2007). Bacillus sp. is highly tolerant to salt concentrations ranging from $2 \%-10 \%$ (Ragul et al., 2017). At $2 \%$ concentration, growth was $7.98 \pm 0.56 \mathrm{Log}$ $\left(\mathrm{CFU} \cdot \mathrm{mL}^{-1}\right)$ and at $10 \%$ concentration, growth was found to be $6.98 \pm 0.29 \mathrm{Log}\left(\mathrm{CFU} \cdot \mathrm{mL}^{-1}\right)$ (Figure 5). An important facet for a probiotic is its ability to survive the action of toxic metabolites like phenol and organic solvents like toluene. Primary phenols are the by-products of the digestive process. Some probiotics retain added bacteriostatic activity by metabolising aromatic amino acids into phenols (Kumar et al., 2019; Suskovic et al., 1997). In this study, isolate was able to tolerate phenol and toluene at $0.6 \%$ concentrations $\left[7.8 \pm 0.08 \mathrm{Log}\left(\mathrm{CFU} \cdot \mathrm{mL}^{-1}\right)\right.$ and $8.5 \pm 0.09$ $\left.\log \left(\mathrm{CFU} \cdot \mathrm{mL}^{-1}\right)\right]$ respectively (Figure 6$)$.

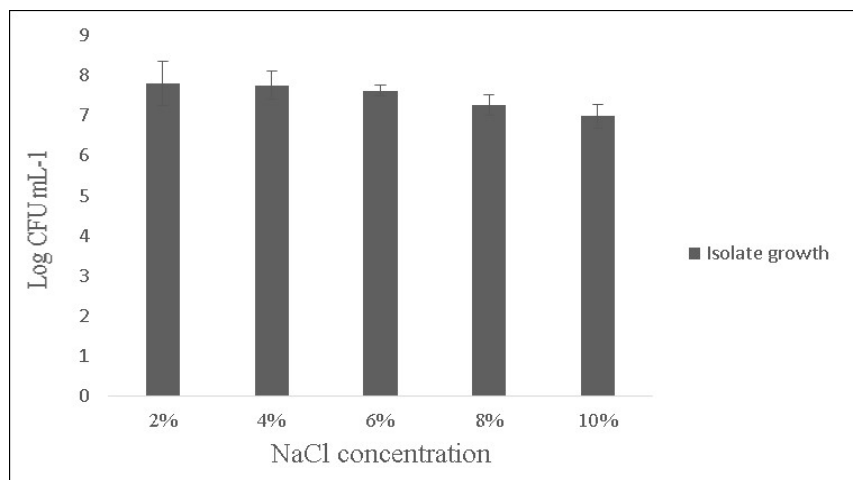

Figure 5: showing the effect of $\mathrm{NaCl}(2-10 \%)$ tolerance on the growth of Bacillus subtilis -MN960600. *Error bars indicate the standard deviation; the values are expressed as Mean \pm SD of triplicates

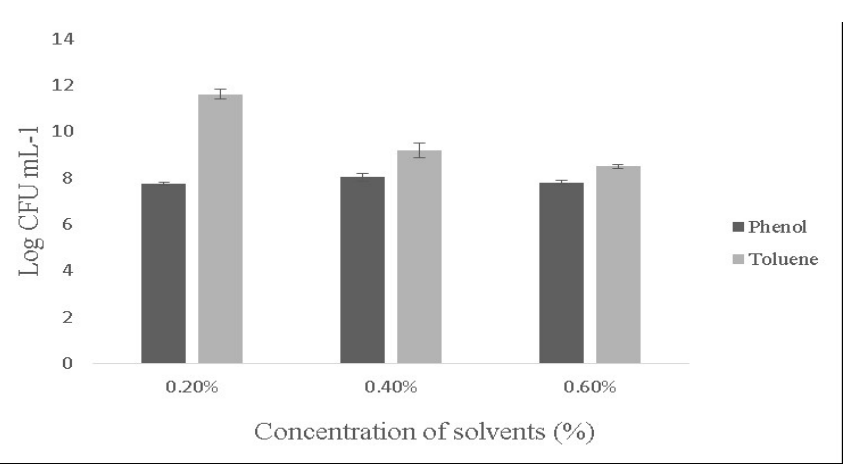

Figure 6: showing the effect of solvents (Phenol and toluene) on the growth of Bacillus subtilis-MN960600. *Error bars indicate the standard deviation; the values are expressed as Mean $\pm \mathrm{SD}$ of triplicates

The anti-biofilm forming activity of the isolate was evaluated against Escherichia coli, Vibrio harveyi, Pseudomonas aeruginosa and Staphylococcus aureus and was found to be $28.8 \pm 4.2 \%, 31.5 \pm 4.6 \%, 34.8 \pm 3.1 \%$ and $34.4 \pm 3.75 \%$ respectively (Figure 7). Bacillus sp. possess remarkable antimicrobial properties which can be attributed to the production of bacteriocins like fengycin, surfactin, bacilysin, butirosin, macrolactin, bacillaene, difficidin, bacillibactin, lanthipeptides and LCI. Antimicrobial peptides are also produced by genes like LCI, YFGAP and hGAPDH and gene clusters for secondary metabolites (Wu et al., 2018). Bacterial motility is crucial for colonization processes of pathogens. Bacillus sp. isolated from a marine niche has been used to decrease Vibrio alginolyticus motility and thereby reduce its pathogenicity against Danio rerio. The potential lead compounds from Bacillus sp. targeting bacterial motility and biofilm inhibition are encouraged to be used in aquaculture. Bacillus sp. have a low potential for eliciting antibiotic resistance since they are not involved in horizontal gene 
transfer and are unlikely to acquire genes pertaining to antibiotic resistance (Xiu et al., 2017).

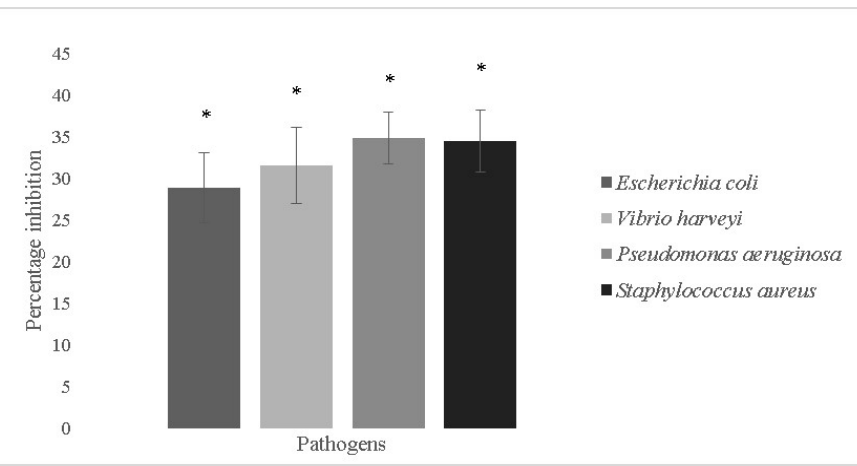

Figure 7: Antibiofilm activity of Bacillus subtilisMN960600 against Escherichia coli, Vibrio harveyi, Pseudomonas aeruginosa and Staphylococcus aureus. ${ }^{*}$ The error bars indicate standard deviation and statistical significance indicated by $*(\mathrm{P}<0.05)$

Feed conversion ratio (FCR) was lesser compared to the control sample indicating a potential of improved nutrition absorbability. Similarly, other growth parameters like length gain and weight gain percentages were found to be better in probiotic supplemented samples but no significant difference in the growth parameters between the control and treatment groups was noted (Table 2).

Table 2: Growth parameters in Danio rerio upon treatment with Bacillus subtilis isolate

\begin{tabular}{|c|c|c|c|}
\hline Parameters & Control & Probiotic & P-value \\
\hline $\begin{array}{l}\text { Feed conversion } \\
\text { ratio }\end{array}$ & $0.32 \pm 0.07$ & $0.27 \pm 0.09^{*}$ & 0.24 \\
\hline $\begin{array}{l}\text { Weight gain } \\
\text { percentage }\end{array}$ & $12.3 \pm 0.08$ & $12.77 \pm 0.06^{*}$ & 0.18 \\
\hline $\begin{array}{l}\text { Length gain } \\
\text { percentage }\end{array}$ & $8.9 \pm 0.32$ & $11.413 \pm 0.18^{*}$ & 0.43 \\
\hline $\begin{array}{l}\text { Note: The values } \\
\text { significance was } \\
\text { and the non-signif } \\
\text { highlighted using * }\end{array}$ & Mean $\pm S D$ & of triplicates, & $\begin{array}{l}\text { the statistical } \\
\text { student } t \text {-test } \\
\text { ween rows are }\end{array}$ \\
\hline
\end{tabular}

Bacillus sp. have been widely used as growth promoters and contribute for improved survival rate (Gatesoupe, 1999). In this study, Bacillus sp. was used to assess the survival of Danio rerio against fish pathogens as described in the survivorship cure (Figure 8). Bacillus spp. improve food absorption by enhancing protease levels, providing resistance against pathogens like $V$. barveyi and luminescent vibrio spp. in both fishes and penieds (Irianto and Austin, 2002; Moriarty, 1999; Lakshmi et al., 2013). Bacillus subtilis stimulates mRNA expression of both pro-inflammatory and anti-inflammatory cytokines in dendritic cells of grass carp via cytokine-related pathways (Zhou et al., 2019). Bacillus amyloliquefaciens $\mathrm{G} 1$ has been used against a wide spectrum of pathogenic Aeromonas hydrophila strains by having a protective antimicrobial action in Anguilla anguilla (Lu et al., 2011). Furthermore, combination cultures of Bacillus sp. have been used to enhance innate immune response in Perca flavescens, thereby contributing to lesser risk of disease susceptibility. Similarly, a combination mixture of Bacillus subtilis and Bacillus licheniformis (BioPlus2B) has been used against Yersinia ruckeri infected trout to improve their survival rate (Raida et al., 2003; Salim and Reda, 2015). Bacillus subtilis has also been used against $A$. hydrophila, Edwardsiella ictaluri, Streptococcus sp. in Cirrbinus cirrhosus, Oncorbynchus mykiss, Ictalurus punctatus, Pangasianodon hypophthalmus, Epinephelus summana and Oreochromis mossambicus to improve their survival rate

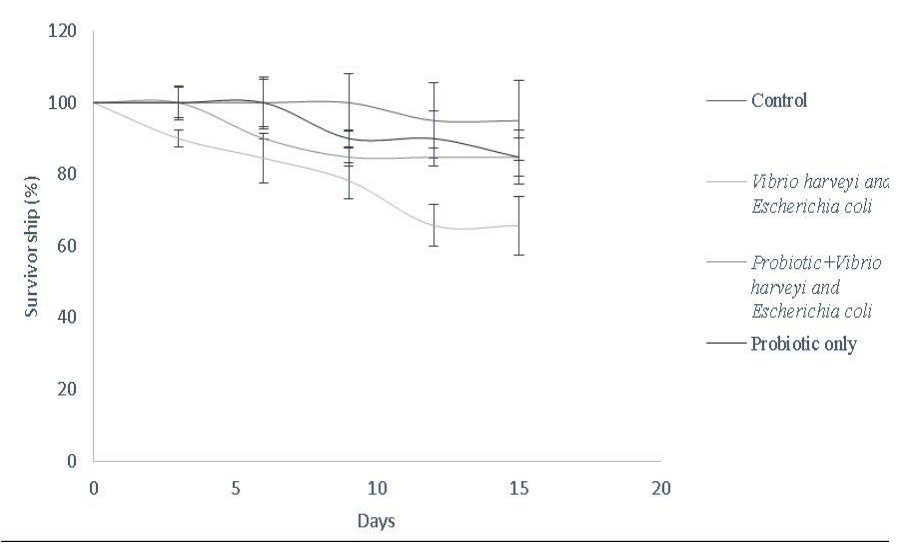

Figure 8: Survivorship curve of D. rerio depicting the effect of B.subtilis- MN960600 supplementation against pathogen challenge in a total duration of 15 days (Control, Vibrio harveyi and Escherichia coli, probiotic+Vibrio harveyi and Escherichia coli and probiotic only). Error bars indicate the standard deviation; the values are expressed as Mean \pm SD of triplicates

(Kumar et al., 2008; Newaj et al., 2007; Ran et al., 2012). Bacillus licheniformis, Bacillus pumilus and Bacillus circulans have been used against Streptococcus agalactiae and $A$. hydrophila in Catla catla, Paralichthys olivaceus and Oreochromis niloticus to improve immune health status and disease resistance (Aly et al., 2008; Babdyopadhyaya and Mohapatra, 2009; Cha et al., 2013; Han et al., 2015). Bacillus sp. S11, NL 110 and B. coagulans have been supplemented to Penaeus monodon, Ictalurus punctatus, Macrobrachium rosenbergii, Cyprinus carpio Litopenaeus vannamei and Fenneropenaeus indicus to improve nutrient digestibility (Queiroz and Boyd, 1998; Rahiman et al., 2010; Rengpipat et al., 1998; Lin et al., 2012; Heizhao et al., 2004). B. subtilis, L. acidophilus, $S$. cerevisiae have been used in Paralichthys olivaceus to improve stress tolerance (Taoka et al., 2006). Bacillus subtilis has also been used in Poecilia reticulata, Xiphophorus maculatus for reproductive enhancement (Ghosh et al., 2007). 


\section{CONCLUSION}

Our study revealed the promising effect of Bacillus subtilis on growth and disease resistance of Danio rerio. Dietary supplementation of Bacillus subtilis as an eco-friendly alternative to antibiotics gained enormous attention in the fisheries sector. Results of our study confirmed the biocontrol potential of Bacillus subtilis against aquaculture pathogens. Widespread research should be conceded out to analyze the species specific interaction of the host and Bacillus subtilis.

\section{ACKNOWLEDGEMENTS}

The authors acknowledge the support received from the Department of Life Sciences and Centre for Research, CHRIST (Deemed to be University) for the financial aid through MRP. (MRPDSC-1936).

\section{CONFLICT OF INTEREST}

The authors declare no conflict of interest

\section{AUTHOR CONTRIBUTION}

Thejaswi Bhandary was involved in the experimental design, data collection, data analysis and revised this manuscript. Riyaz Ali.L was involved in experimental design, data analysis and drafted this manuscript. Kuppusamy Alagesan Paari conceptualized the idea, involved in funding and revised this manuscript. All authors read and approved this manuscript.

\section{REFERENCES}

-Adnan MAF, Tan IK (2007). Isolation of lactic acid bacteria from Malaysian foods and assessment of the isolates for industrial potential. Bioresour. Technol. 98(7):1380-5. https://doi.org/ 10.1016/j.biortech.2006.05.034

-Alkalbani NS, Turner MS, Ayyash MM (2019). Isolation, identification, and potential probiotic characterization of isolated lactic acid bacteria and in vitro investigation of the cytotoxicity, antioxidant, and antidiabetic activities in fermented sausage. Microb. Cell Factories. 18(1):188. https://doi.org/10.1186/s12934-019-1239-1

-Aly SM, Mohamed MF, John G (2008). Effect of probiotics on the survival, growth and challenge infection in Tilapia nilotica (Oreochromis niloticus). Aquac. Res. 39: 647-656. https://doi.org/10.1111/j.1365-2109.2008.01932.x.

- Bandyopadhyay P, Das Mohapatra PK (2009). Effect of a probiotic bacterium Bacillus circulans $\mathrm{PB} 7$ in the formulated diets on growth, nutritional quality and immunity of Catla catla(Ham). Fish Physiol. Biochem. 35(3):467-478. https:// doi.org/10.1007/s10695-008-9272-8.

- Banerjee G, Ray AK (2017). The advancement of probiotics research and its application in fish farming industries. Res.Vet.Sci. 115: 66-77. https://doi.org/10.1016/j.

\section{rvsc.2017.01.016.}

- Bharda S, Desai AY, Kumar TR, Kumar TJ (2017). Production of different type of dry fish and its yield measurement at Veraval, Gujarat. India. Res. J. Recent Sci. 6(7): 28-32.

- Cha JH, Rahimnejad S, Yang SY, Kim KW, Lee KJ (2013). Evalutations of Bacillus spp.as dietary additives on growth performance, innate immunity and disease resistance of olive flounder (Paralichthys olivaceus) against Streptococcus iniae and as water additives. Aquaculture. 402: 50-57. https://doi. org/10.1016/j. aquaculture.2013.03.030.

- Champagne CP, Girard F, Rodrigue N (1993). Production of concentrated suspensions of thermophilic lactic acid bacteria in calcium-alginate beads. Int. Dairy. J. 3(3): 257-275.

- Corcoran BM, Stanton C, Fitzgerald GF, Ross RP (2005). Survival of Probiotic Lactobacilli in Acidic Environments Is Enhanced in the Presence of Metabolizable Sugars. Appl .Environ. Microbiol. 71(6): 3060-3067. https://doi. org/10.1590/0001-3765201820160131.

- Costa GA, Rossatto F, Medeiros CP, Correa AW (2018). Evaluation antibacterial and antibiofilm activity of the antimicrobial peptide P34 against Staphylococcus aureus and Enterococcus faecalis. Anais da Academia Brasileira de Ciências. 90(1): 73-84. https://doi.org/10.1128/ AEM.71.6.3060-3067.2005.

- Cotter PD, Hill C (2003). Surviving the acid test: responses of gram-positive bacteria to low $\mathrm{pH}$. Microbiol. Mol. Bio. Rev. 67(3):429-53. https://doi.org/10.1128/mmbr.67.3.429453.2003.

-Ding WK, Shah JK (2007). Acid, Bile, and Heat Tolerance of Free and Microencapsulated Probiotic Bacteria. J. Food Sci. 72(9): 447. https://doi.org/10.1111/j.17503841.2007.00565.x.

-FAO (2018). The State of World Fisheries and Aquaculture 2018-Meeting the sustainable development goals. Retrieved from: https://www.fao.org/documents/card/en/c/ I9540EN/; accessed on 09/09/2020.

- Fuller R (1989). Probiotics in man and animals. J. Appl. Bacteriol. 66: 365-378.

- Gaspar C, Donders GG, Palmeira DOR, Queiroz JA, Tomaz C, Martinez-de-Oliveira J, Palmeira-de-Oliveira A (2018). Bacteriocin production of the probiotic Lactobacillus acidophilus KS400. AMB Express. 8(1): 153. https://doi. org/10.1186/s13568-018-0679-z.

- Gatesoupe FJ (1999). The Use of Probiotics in Aquaculture. Aquaculture.180: 147-165.

-Gayathri D, Rashmi BS (2016). Anti-cancer properties of probiotics: a natural strategy for cancer prevention. EC Nutrition. 5: 1191-1202.

- Ghosh S, Sinha A, Sahu C (2007). Effect of probiotic on reproductive performance in female livebearing ornamental fish. Aquac. Res. 38:518-526.

- Halder D, Mandal M, Chatterjee S, Mandal S (2017). Indigenous Probiotic Lactobacillus Isolates Presenting Antibiotic like Activity against Human Pathogenic Bacteria. Biomedicines. 5. https://doi.org/10.3390/biomedicines5020031.

- Han B, Long W Q,He JY, Liu YJ, Si YQ,Tian LX(2015). Effects of dietary Bacillus licheniformis on growth performance, immunological parameters, intestinal morphology and resistance of juvenile Nile tilapia (Oreochromis niloticus) to challenge infections. Fish Shellfish Immunol. 46:225-231. https://doi.org/10.1016/j.fsi.2015.06.018.

-Heizhao Z, Zhixun G, Yingying Y, Wenhui Z, Zhuojia J (2004) .Effect of dietary probiotics on apparent digestibility 
coefficients of nutrients of white shrimp Litopenaeus vannamei Boone. Aquac. Res .35:1441-1447.

-Hols P, Ledesma-García L, Gabant P, Mignolet J. (2019). Mobilization of microbiota commensals and their bacteriocins for therapeutics. Trends Microbiol. 27:690-702. https://doi.org/10.1016/j.tim.2019.03.007.

-Hoque MZ, Akter F, Hossain K, Islam KMD (2010). Isolation, Identification and Analysis of Probiotic Properties of Lactobacillus Spp. From Selective Regional Yoghurts. World J. Dairy Food Sci. 5: 39-46.

- Hoseinifar SH, Sun YZ, Wang A, Zhou Z (2018). Probiotics as Means of Diseases Control in Aquaculture, a Review of Current Knowledge and Future Perspectives.Front Microbiol. 9: 2429. https://doi.org/10.3389/fmicb.2018.02429

-Irianto A, Austin B. Probiotics in Aquaculture (2002). J. Fish Dis. 25: 633-642.

-Jeon HL, Lee NK, Yang SJ, Kim WS, Paik HD (2017). Probiotic characterization of Bacillus subtilis P223 isolated from kimchi. Food Sci Biotechnol. Biotechnol. 13:1641-1648. https://doi.org/10.1007/s10068-017-0148-5.

-Kavitha M, Raja M, Perumal P (2018). Evaluation of probiotic potential of Bacillus spp. isolated from the digestive tract of freshwater fish Labeo calbasu (Hamilton, 1822). Aquac. Rep. 11:59-69. https://doi.org/10.1016/j.aqrep.2018.07.001.

• Kerry RG,Patra JK., Gouda S., Park Y., Shin HS., Das G. (2018). Benefaction of probiotics for human health: A review. J. Food Drug Anal. 26(3): 927-939. https://doi.org/10.1016/j. jfda.2018.01.002

-Kong W., Huang C., Tang Y., Zhang D., Wu Z., Chen X.(2017). Effect of Bacillus subtilis on Aeromonas hydrophilainduced intestinal mucosal barrier function damage and inflammation in grass carp (Ctenopharyngodon idella). Sci. Rep. 7:1588. https://doi.org/10.1038/s41598-017-01336-9.

-Krulwich TA, Agus R, Schneier M, Guffanti AA (1985). Buffering capacity of Bacilli that grow at different $\mathrm{pH}$ ranges. J. Bacteriol. 162:768-72.

- Kumar R, Mukherjee S, Ranjan R, Nayak S (2008). Enhanced innate immune parameters in Labeo rohita (Ham.) following oral administration of Bacillus subtilis. Fish Shellfish. Immunol. 24: 168-172. https://doi.org/10.1016/j. fsi.2007.10.008.

- Kumar SA, Cabral C, Kumar R, Ganguly R, Kumar Rana, H, Gupta A, Rosaria Lauro M, Carbone C, Reis F, Pandey AK (2019). Beneficial Effects of Dietary Polyphenols on Gut Microbiota and Strategies to Improve Delivery Efficiency. Nutrients. 11(9). 2216. https://doi.org/10.3390/ nu11092216.

-Lakshmi B, Viswanath B, Sai Gopal DVR (2013). Probiotics as Antiviral Agents in Shrimp Aquaculture. J. Pathog. https:// doi.org/10.1155/2013/424123.

- Lin Sh Y, Guan L, Luo, Pan Y (2012).Effects of dietary chitosan oligosaccharides and Bacillus coagulans on growth, innate immunity and resistance of koi (Cyprinus carpio koi). Aquaculture. 342-343:36-41.

- Liu CH, Chiu CH, Wang SW, Cheng W (2012). Dietary administration of the probiotic, Bacillus subtilis E20, enhances the growth, innate immune responses, and disease resistance of the grouper. Epinephelus coioides. Fish Shellfish. Immunol. 33:699-706. https://doi.org/ 10.1016/j.fsi.2012.06.012.

- Liu CH, Chiu CS, Ho PL, Wang SW (2009). Improvement in the growth performance of white shrimp, Litopenaeus vannamei, by a protease-producing probiotic, Bacillus subtilis E20, from natto. J. Appl. Microbiol. 107(3): 1031-1041. https://doi.org/10.1111/j.1365-2672.2009.04284.x.

-Logesh AR, Pravinkumar M, Raffi SM, Kalaiselvam M (2012). An investigation on microbial screening on salt dried marine fishes. J. Food. Resour. Sci. 1(1): 15-21. https://doi. org/10.3923/jfrs.2012.15.21

-Lu L, Cao H, He S, Wei R, Diong M (2011). Bacillus amyloliquefaciens $\mathrm{G1}$ : A potential antagonistic bacterium against eel-pathogenic Aeromonas hydrophila. eCAM. 2011(5):824104 https://doi.org/10.1155/2011/824104.

- Lu Z, Guo W, Liu C (2018) Isolation, identification and characterization of novel Bacillus subtilis. J.Vet. Med.Sci. 80(3):427-433. https://doi.org/10.1292/jvms.16-0572.

-Moriarty DJW (1998) .Control of luminous Vibrio species in penaeid aquaculture ponds. Aquaculture.164:351-358.

-Newaj-Fyzul , Adesiyun AA, Mutani A,Ramsubhag A, Brunt J, Austin,B (2007).Bacillus subtilis AB1 controls Aeromonas infection in rainbow trout (Oncorbynchus mykiss, Walbaum). J. Appl. Microbiol. 103(5):1699-1706. https://doi. org/10.1111/j.1365-2672.2007.03402.x.

- Nithya V, Halami PM (2012).Evaluation of the probiotic characteristics of Bacillus species isolated from different food sources. Ann. Microbiol. 63:129-37. https://doi.org/ 10.1007/s13213-012-0453-4.

- Orrhage K, Sillerström E, Gustafsson JA, Nord CE, Rafter $\mathrm{J}$ (1994). Binding of mutagenic heterocyclic amines by intestinal and lactic acid bacteria. Mut. Res. 311(2):239-248. https://doi.org/ 10.1016/0027-5107(94)90182-1.

- Panda SH, Goli JK, Das S, Mohanty N (2017). Production, optimization and probiotic characterization of potential lactic acid bacteria producing siderophores. AIMS Microbiol. 3(1): 88-107. https://dx.doi. org/10.3934\%2Fmicrobiol.2017.1.88.

-Pavlova AS, Ozhegov GD, Arapidi GP, Butenko IO, Fomin ES, Alemasov NA, Kayumov AR (2020). Identification of Antimicrobial Peptides from Novel Lactobacillus fermentum Strain. Protein J.39:73-84. https://doi.org/10.1007/s10930019-09879-8.

- Pereira DI, Gibson GR (2002). Effects of Consumption of Probiotics and Prebiotics on Serum Lipid Levels in Humans. Crit. Rev. Biochem. Mol. Biol. 37(4):259-281. https://doi. org/10.1080/10409230290771519.

- Queiroz JF, Boyd CE (1998). Effects of a bacterial inoculum in channel catfish ponds. J. World Aquac. Soc. 29(1):67-73. https://doi.org/10.1111/j.1749-7345.1998.tb00300.x.

- Ragul K, Syiem I, Sundar K, Shetty PH (2017). Characterization of probiotic potential of Bacillus species isolated from a traditional brine pickle. J. Food. Sci.Tech. 54(13):44734483. https://doi.org/10.1007/s13197-017-2928-6.

- Rahiman M, Yousuf J, Ambat T, Hatha M (2010). Probiotic effect of Bacillus NL110 and Vibrio NE17 on the survival, growth performance and immune response of Macrobrachium rosenbergii (de Man). Aquac. Res. 41:120-134. https://doi. org/10.1111/j.1365-2109.2009.02473.x.

- Raida MK, Larsen JL, Nielsen ME, Buchmann K (2003). Enhanced resistance of rainbow trout (Oncorbynchus myskiss) against Yersinia ruckeri challenge following oral administration of Bacillus subtilis and B. licheniformis (Bio plus 2B). J. Fish Dis. 26(8):495-498. https://doi. org/10.1046/j.1365-2761.2003.00480.x.

- Ran C, Carrias A, Williams MA, Capps N, Dan BCT (2012). Identification of Bacillus strains for biological control of catfish pathogens. PLoS ONE. 7(9): e45793. https://doi. org/ 10.1371/journal.pone.0045793. 
- Rengpipat S, Phianphak W, Piyatiratitivorakul S, Menasveta P (1998). Effects of a probiotic bacterium on black tiger shrimp Penaeus monodon survival and growth. Aquaculture. 167(3-4):301-313. https://doi.org/10.1016/S00448486(98)00305-6.

-Santos L, Ramos F (2018). Antimicrobial resistance in aquaculture: current knowledge and alternatives to tackle the problem. Int. J. Antimicrob. Agents. 52(2): 135-143. https:// doi.org/10.1016/j.ijantimicag.2018.03.010.

- Satish Kumar R, Kanmani P, Yuvaraj N., Paari KA, Pattukumar V, Arul V (2011). Purification and characterization of enterocin MC13 produced by a potential aquaculture probiont Enterococcus faecium MC13 isolated from the gut of Mugil cephalus. Canadian. J. Microbiol. 57(12): 993-1001. https://doi.org/10.1139/w11-092.

- Seenivasan C, Radhakrishnan S, Muralisankar T, Saravana Bhavan P (2012).Bacillus subtilis on survival, growth, biochemical constituents and energy utilization of the freshwater prawn Macrobrachium rosenbergii post larvae. Egypt. J. Aquat. Res. 38(3):195-203.https://doi. org/10.1016/j.ejar.2012.12.009.

- Selim KM, Reda RM (2015). Improvement of immunity and disease resistance in the Nile tilapia, Oreochromis niloticus, by dietary supplementation with Bacillus amyloliquefaciens. Fish Shellfish. Immunol. 44(2): 496-503. https://doi. org/10.1016/j.fsi.2015.03.004.

- Sen R, Tripathy S, Padhi SK, Mohanty S, Maiti NK (2015). Assessment of genetic diversity of Bacillus spp. isolated from eutrophic fish culture pond. 3 Biotech. 5(4):393-400. https://doi.org/ 10.1007/s13205-014-0234-9.

- Shishehchian F, Yusoff FM, Shariff M (2001).The effects of commercial bacterial products on macro benthos community in shrimp culture ponds. Aquac. Int. 9: 429-436. https://doi. org/10.1023/A:1020582417487.

- Singh AK, Mukherjee S, Adhikari MD, Ramesh A (2012). Fluorescence-based comparative evaluation of bactericidal potency and food application potential of anti-listerial bacteriocin produced by lactic acid bacteria isolated from indigenous samples. Probiotics. Antimicrob. Proteins. 4(2): 122-132. https://10.1007/s12602-012-9100-4.

- Siriskar DA, Khedkar GD, Lior D (2013). Production of salted and pressed anchovies (Stolephorus sp.) and its quality evaluation during storage. J. Food. Sci. Tech. 50(6): 11721178. https://doi.org/10.1007/s13197-011-0450-9.

-Suskovic J, Brkic B,Matosic S, Maric V (1997). Lactobacillus acidophilus M92 as potential probiotic strain, Milchwissenschaft, 52(8):430-435.

- Tamura K, Nei M (1993). Estimation of the number of nucleotide substitutions in the control region of mitochondrial DNA in humans and chimpanzees. Mol. Biol. Evol. 10(3):512-526. https://doi.org/10.1093/oxfordjournals.molbev.a040023.

- Taoka Y, Maeda H, Jo JY (2006). Growth, stress tolerance and non-specific immune response of Japanese flounder Paralichthys olivaceus to probiotics in a closed recirculating system. Fish.Sci. 72(2):310-321. https://doi.org/10.1111/ j.1444-2906.2006.01152.x.

-Wang YB, Qiang Z, Jiang-Ta T, Weifen Y, Li LW (2008). Effect of probiotics, Enterococcus faecium, on tilapia (Oreochromis niloticus) growth performance and immune response. Aquaculture. 277(3): 203-207. https://10.1016/j. aquaculture.2008.03.007.

-Wu F, Chang C, Shih I (2013).Optimization of the production and characterization of milk clotting enzymes by Bacillus subtilis natto. SpringerPlus. 2(1):33. https://doi. org/10.1186/2193-1801-2-3.

-Wu J, Xu G, Jin Y, Sun C, Zhou L, Lin G, Xu R, Wei L, Fei $\mathrm{H}$, Wang D, Chen J, Lv Z, Liu K (2018). Isolation and characterization of Bacillus sp. GFP-2, a novel Bacillus strain with antimicrobial activities, from Whitespotted bamboo shark intestine. AMB Express. 8(1):84. https://doi. org/10.1186/s13568-018-0614-3.

-Xiu P, Liu R, Zhang D, Sun C (2017). Pumilacidin-Like Lipopeptides Derived from Marine Bacterium Bacillus sp. Strain 176 Suppress the Motility of Vibrio alginolyticus. Appl. Env. Microbiol. 83(12): 450-17. https://doi.org/10.1128/ AEM.00450-17.

- Yadav R, Puniya AK, Shukla P (2016). Probiotic Properties of Lactobacillus plantarum RYPR1 from an Indigenous Fermented Beverage Raabadi. Front. Microbiol. 7: 1683. https://doi.org/ 10.3389/fmicb.2016.01683.

-Zheng Y, Lu. Y, Wang. J, Yang. L, Pan. C, Huang Y (2013). Pro-biotic properties of Lactobacillus strains isolated from Tibetan kefir grains. PLoS One. 8(7): e69868. https://doi. org/ 10.1371/journal.pone.0069868.

-Zhou C, Wang H, Li X, Luo Y, Xie M, Wu Z, Chen X. (2019). Regulatory Effect of Bacillus subtilis on Cytokines of Dendritic Cells in Grass Carp (Ctenopharyngodon Idella). Int. J. Mol. Sci. 20(2):389. https://doi.org/10.3390/ ijms20020389.

-Zhou S, Xia Y, Zhu C, Chu W (2018).Isolation of Marine Bacillus sp. with Antagonistic and Organic-SubstancesDegrading Activities and Its Potential Application as a Fish Probiotic. Mar. Drugs. 16(6):196. https://doi.org/10.3390/ md16060196.

-Zhou XX, Wang YB, Li WF (2009). Effect of probiotic on larvae shrimp(Penaeus vannamei) based on water quality, survival rate and digestive enzyme activities. Aquaculture. vol. 287(3-4):349-353. https://doi.org/10.1016/j. aquaculture.2008.10.046.

-Zielińska D, Kolożyn-Krajewska D (2018). Food-origin lactic acid bacteria may exhibit probiotic properties.Bio. Med. Res Int. 2018: 5063185. https://doi.org/10.1155/2018/5063185.

-Zulkhairi AFA, Sabri S, Ismail M, Chan KW, Ismail N, Mohd Esa N (2019). Probiotic Properties of Bacillus Strains Isolated from Stingless Bee (Heterotrigona itama) Honey Collected across Malaysia. Int. J. Environ. Res. Public Health. 17(1):278. https://doi.org/ 10.3390/ijerph17010278 